Paediatrica Indonesiana $15: 303$ - 314. Nov. - Dec. 1975. 303

Fron the Department of Child Health, Medical School, University of North Sumatra and Tuberculosis Control, Provincial Health Service of North Sumatra

\title{
Tuberculosis in Children and BCG Vaccination in North Sumatra
}

\section{by}

IO KIAN TJAY, ROBENCIUS SARAGIH, SAHAT HALIM, TJUT' IRAWATI, P. HARNOPIDJATI, S.M. MANOEROENG and M.V.O. SITOMPUL

\begin{abstract}
Data of child tuberculosis, clinical visits and those who were treated in the three hospitals, visits to the 6 public health centers (Puskesmas) and figures of BCG immunization in the North Sumatra Province were presented.

Although the tuberculin index in children in Medan (1965) was lower than that in Java (BCG Mass Campaign, 1954 - 1964), primary tuberculosis Fatients treated in the General Hospual (RSUPP) constituted $1.14 \%$ of the total patients admitted to the hospital in 1963 - 1972, whereas in the "PNP IX" hospital it was $0.84 \%$. From a survey of families (1962 - 1969) it revealed that infection in the families was $\pm 50 \%$. While $76.1 \%$ of the meningitis patients were under the age of 4 years. From a survey of 6 public health centers we found through a Pilot Project that $1.02 \%$ patients had a positive sputum. The above mentioned figures gave the indication that BCG immunization had to be performed in children under the age of 4 years. However, the figures of the BCG campaign (1970 - 1973) at the above mentioned Pilot Project revealed that coverage in the under 5 - years - cld age was $20.5 \%$, whereas in the $5-14$ years age group it was $49.2 \%$.

In practice the realization of massal BCG immunization was certainly the simplest with school age children who were already grouped and registered; lievertheless, partly of them hat already got infected and had been released from tuberculous meningitis complication. BCG immunization as mentionea above (probably it was also given in other areas in Indonesia) did obviously not reach its right target.
\end{abstract}

Received 11th Sept. 1974. 


\section{Introduction}

Tuberoulasils in Indonesia is still a public health problem and is one of the main causes of death. After the TB/BCG workshop in Cilloto, January 1969 , the Ministry of heaith has taken steps in the prevention and therapy of tuberculosilis, such as BCG vaccination without pre-test in children of 0-14 years, and supervision of intermittent chemoitherapy to adult patients with a positive sputum in every Province. At the first Congress of the Indonesian Tuberculosis Association, Jakarta Jully 1973, one of the decisions was to assilst the Government in the eradication programme of tuberculosis and especially that of pulmonary tuberculosis.

This paper will deal with a survey of tuberculosis in children in 3 hospitals ln Medan (1959-1972), the BCG vaccination in North Sumatra (19701973) and the results of the isupervised ambulatory treatment of tuberculasis in the Pilot Project TB Control in the Health Centre of Stabat (1971-1973).

\section{Material and Method}

Private practice in the Elisibuth Hospital (1959-1960):

Nine hundred and twenty children under the age of 6 years and 130 children in the age group of 6-12 years were tested with tuberculin (Mantoux test), 909 and 126 children of each group respectively returned.
The Mantoux test was carried out with $1 / 100$ of Old Tuberculin and was read after $3 \times 24$ hours. It was interpreted positive when the induration was $10 \times 10 \mathrm{~mm}$ or more.

This Mantoux test was carried out in the Hospital and in the field survey as well. The reason for using 1/100 concentration of Old Tubercuilin is primarily to reduce the number of drop outs.

The O.P.D. an the Top Provincial Refermal Hospital (RSUPP 1961-1965) :

Fifteen thousand and ten children (under the age of 6 years) and 1948 chilldren (age group 6-12 years) were tested with the Manitoux test, 9682 and 1182 children of each group respectively returned.

The in-patients in the RSUPP and PNP-IG hospital (1962-1969):

As a routine all the admitted children were tested with tuberculin. When the Mantoux itest was positive, chesit X-ray films were made and the aliblings unider the age of 5 years were also tested. Their parents were sent to the chest clinic for check up and the isputum was examined with the Ziehl-Neelsen method, when a lung procesis was present. The sputum of the children was not examined.

The tuberculosis patients from the Chest Clinic (1962-1969):

In 29 famillies in which both of the parents had tuberculosis, the 
children were tested and chest X-ray films made when the Mantoux test was positive.

Follow up (home visit) studies $(1969-1971)$ :

A pediatrician together with some nurses from the Chest Clinilc made home visits for a follow up study of the children from tuberculous families, whose previous Mantoux tests were negative.

All patients loudmatted with convulsion $(1964-1972)$ :

Their cerebrospinal fluild (CSF) was examined. When the CSF was clear, the Pandly and Nonne reaction was positive, and the cell count more than $20 / \mathrm{mm}^{3}$ with predominantly lymphocytes, with either a positive or negative tuberculin test, it was considdered as tuberculous meningitis.

\section{Chest $X$-rnay films (1970-1972):}

A survey was made of the chest $X$-ray fillms from the chilid'ren admitted with tuberculasis. In general only the postero-anterior photo was made. $A_{i}{ }_{i}$ the readling the lung fileld was divided into approximately 3 equal fieldls: the upper $1 / 3$, the mid $1 / 3$ and the lower $1 / 3$. Only distinct lesions were classified.

The BCG vaccination in North Sumatna (1970 - March 1973):

It was carried out with the sweeping system until April 1973, while since April 1973 it was included in the immunization programme (carri ed out with the smallpox vacoination).

The BCG vaccination was done by paramedical personnel afiter getting some training, and it was applied to chilldren in the elementary schood (age group 6-14 years).

Toddlers and older children who did not attend school were gathered by the Head of the "kampung" and vaccinated accordling to the date and place announced in advance. With the sweeping system the BCG vaccination was carried out in each regency, one after another.

The BCG vaccination in the PNPIX tobacco plantation was done together with the routine chotypa (Cholera, Typhus and paratyphoid vaccine) injectlion and smallpox inoculation. Labourers, employees and. their families were regularly vaccinated every 6 months.

Babies under the age of 3 months got , only $B C G$ vaccination, between the age of 2-3 moniths - 1 year BCG and smallpox vaccination were done at the same tilme. Children over 1 year of age got chotypa injection and smallpox revaccination together with BCG.

In the RSUPP, newborn babies (1-5 days old) were vaccinated with BCG before leaving the maternity ward. 
After BCG vaccination a Mantoux test survey was conducted on 237 infants out of 2175 in the RSUPP vaccinated newborns, on 261 children (1-14 years old) in PNP-IX and on 167 children (1-6 years old) in $\mathrm{Ka}$ banjahe (Tanah Karo), who all had been vaccinated with BCG 3 months to 2 years before and who had a scar in the regio deltoideus dextra.

There are 6 TB Control Pillat Projects in North Sumatra and one of these is the Health Centre Stabat. In this Pilot Project the BCG vacaination was performed by sweeping system; the TB patients (most of them aduits) were given free medical treatment. Before starting this project a TB campaign was helld: all persons, who coughed for more than 2 weeks or with bloody sputum, were advised to visit the Health Centre for examination.

The diagnosis of TBC was only based on the finding of the Mycobacterium in the sputum (no X-ray examination). If the sputum was negative on the first examination, it was re-examined 3 times in a week.

The patilents with positive sputum were treated twice weekly with Streptomycine injection 1 gram and $\mathrm{INH} 14 \mathrm{mg} / \mathrm{kg}$ BW and $B_{6} 10 \mathrm{mg}$ orally.

The tuberculous process was classified as "quiescent" when on the 10th, 11th, 12th monith the sputum had become negative. During the quilescent period the patients got INH $400 \mathrm{mg}, \mathrm{B}_{6} 10 \mathrm{mg}$ daily for one year. Control (home visit) was conduoted every 3-6 months, depending on the distance between the HC and the patient's residence. After one year of quiescence, the TB process was classifified as "cured" and no treatment was given; neventheless they still had to be controlled every six months. If after one year of treatment the sputum remained positive, the patients were sent to the Referral Hospital for consultation and further treatment.

\section{Restults}

I. Out-patients department/priva. te practice Elisabeth Hospital (1959. 1962) : 56 out of 909 children (aged 3 months - 6 yelars) or $6.2 \%$ and 27 out of 126 children (aged 6-12 years) or $21.4 \%$ showed a positive test.

II. Out-patients department RSUPP (1961-1963) : 332 out of 9682 children (aged 3 months - 6 years) or $3.4 \%$ and 170 out of 1183 children (aged $6-12$ years) or $14.4 \%$ had a positive tuberculine test.

III. Fifty-one families belonging to 66 chldren (aged 4 months - 5 years) with la positive tuberculin reaction (1962-1966) were checked for fluoroscopy and sputum examination with the following results (these 66 children consisted of 14 children from the PNP-IX hospital and 52 children from the RSUPP): 
a. in 15 families fathers and mothers were checked': all the 15 fathers showed some lesion on fluoroscopy (one with a cavity), 5 fathers had posiltive sputum, one was nogative and on the others there were no data about the sputum. Also all the 12 mothers showed pulmonary lestion, 3 had positive sputum, one was negative and on the others were no data.

b. in 5 famillies only mothers were checked: all the mothers showed pulmonary lesions (two with a cavity), 2 had positive sputum, and on the 3 others were no data.

c. in 5 families only fathers were checked: all the fathers showed pulmonary lesions, but none had positive sputum.

d. in 24 out of 51 families or $47 \%$, the parents had no pulmonary lesilons; but there were 4 grandmathers (ine of them had positive sputum); one aunt and two uncles showed pulmonary lesions.

IV. Parents with tuberculosis (Chest Clinic) from 29 families had infected their children (under the age of 5 years). Ten fathers with positive sputum infected 10 of their children. In 6 other families, mothers with positive sputum infected 11 of their childiren. In one family, both father and mother with positive sputum infected 2 of their children. From the rema:ming 12 families or $41 \%$ - consisting of 7 fathers with positive sputum - at the beginning they did not infect their children but 5 years afterwards in 7 families with 7 fathers and one mother with positive sputum those "escaped" children were eventually infected, and so were 11 of their siblings below the age of 5 years.

Three out of 66 hospitalized patients died; one died with milliary tuberculosis, one w:th tuberculous meningitis and one with spondylitis. Further data of the other 63 patients after d:scharge were not known.

V. Tuberculous meningitis (19641972) (see table 1 and 2):

Out of 312 children with meningitis, 242 or $77.5 \%$ were under 5 years of age and 70 or $22.5 \%$ were older. One hundred and forty nine children $(47.8 \%)$ died, 119 children out of 149 or $79.7 \%$ were under 5 years of age and 30 children $(20.3 \%)$ were above this group (see table 1). Nearly all the admitted chllidren were seriously ill and also in poor nutriti. onal condlition. The mortality rate within the first 24 hours was $28.2 \%$. Only 62 children out of $312(26.8 \%)$ had a positive Mantoux test, from 13 children the CSF Was sent for bacteriological examination but no Mycobacterium was found on culture. Only 15 familises of the pattients could be 
examined, 9 of them had specific pulmonary lesions and in 4 families the father was illi.

The statistics concerning tuberculous meningitis in Bandung, Jakarta, Makasar, Yogya and Surabaya also showed that the prevalence and the mortallity were very high in young children below the age of 5 years (see tabile 2).

\section{Nutritional status}

Eighty-six children out of 231 patients $(37.7 \%)$ wiith tuberculous meningitis (RSUPP and PNP-IX) were undernourished in a moderate to severe degree, according to the classification of Gomez (Poey Seng Hin, 1956).

VII. X-ray lesions (see table 3):

During 1970-1972 a survey of the chest X-ray fillms was carried out on all admitted tuberculous patients: in RSUPP 142 children and in RS PNP IX 88 children. The lesions variled from marked linear streaks, patchy, mild to masisive consolidation and milliary lesilons. As mentioned above, the lesions were classified as being present in the one third upper, middle and lower part and not according to the segmental division, because no $\mathrm{X}$-ray in lateral position was madle. The results were as follows: in the right upper field 54, in the left, upper field 34 , in the right middle field 163, in the left middie field 118, in the right lower field 132 , in the left lower fileld 41 , and in 13 with milliary lesions. So the lesions were located mainly in the upper right and in the middle lung field. Masslive consolidations were found only in 45 children.

VIII. Results of the supervised intermittent chemotherapy in the Pilot Project TB Control at Stabat Health Center (1971-1973) :

In the second year of treatment, 96 patients $(83.5 \%)$ out of 115 were classified as quiescent. There were 19 drop out patients $(16.5 \%): 8$ patients who lived far from the Health Center. There were 2 patients who dlied after 9 months of treatment, one patient moved to another place and 8 other patients could not be traced. In the thind year of treatment 93 patients $(96.8 \%)$ were classified as cured.

IX. BCG vaccination in North Sumatra (see table 4)

The population of North Sumatra according to the age group was as follows: 0 - 4 years $1.283 .299,5-14$ years 2.114 .026 and above 15 years 3.621.704. The target of the BCG vaccination with at least $75 \%$ coverage in the age group below 14 yearold was estimated as 2.847 .600 children. But in the period of 3 years (1970 - 1973) the coverage was only $34.4 \%$ or 1.169 .290 children. When classified in the three age groups the 
coverage was as follows: $0-4$ years $27.7 \%$ (348.578), 5 - 14 years $38.8 \%$ (820.712) and above 15 yeans $0.9 \%$ (32.483). The coverage of the BCG vaccination at Stabat Health Center in the age group of $0-4$ years was $20.5 \%$, of $5-14$ years it was $49.2 \%$ and in the age group above 15 years it was $3.2 \%$. However, there were some districts in North Sumatra which had a coverage rate of more than $75 \%$ such as in the regency of Karo, the towns of Binjai, Tebing Tinggi and the PNP-IX plantation. The high coverage in T. Karo was achieved due to the medical mindedness of the population and the support given by the regency in the form of providing transport expenses and financial incentive to the vaccinators, in adidition to the financial incentive given by the Health department. In the towns of Tebing Tinggi and Binjai the population is small, so the entire children popuiation could easily be covered. In the PNP-IX estate the coverage was also high due to the existing system of routine immunization every 6 months as mentioned above.

\section{Discussion}

During 1959 - 1973 in the three hospiitals in Medan, all the admitted chilidren were routinely tested with Old Tuberculin. During that period 66 children (from 51 families) runder the age of 5 years suffering from all kind's of diseases had a positive Man- toux test. Twenty-seven out of these 51 families $(53 \%)$, either the father or the mother, had pulmonary tuberculosis with positive sputum and besides there was also a grandfather with positive sputum. On the other hand in 22 families with the parents suffering from pulmonary tuberculosis with positive sputum, the children under the age of 5 years were also infected. In 9 families $(60 \%)$ out of 15 with children suffering from tuberculous meningitis, it was found that either the father or the mother was the source of infection. In other words about $50 \%$ of the tuberculous infection in children occurred in families with parents suffering from pulmonary tuberculosis. From 312 children of the age of 3 months to 14 years suffering from tuberculous meningitis it was found that $\mathbf{7 7 . 5 \%}$ were under the age of 5 years, and the highest mortality rate $(79.7 \%)$ was also found in the same age group. So it is clear that children under the age of 5 years were vulnerable and these should be prevented from tuberculous infection.

Since 1970 the Health Department in North Sumatra has started the TB eradication program, i.e. BCG vaccination without preceding test has been performed in children of 0 - 14 years old' and in some heaith centers - as a pilot project supervised ambulatory intermittent chemotherapy was given in patients with pulmonary tuberculosis (mostly 
adults) with positive sputum (Ciloto, 1969). The resulits in one of the Health Centers (Stabat) were excellent: 96,8\% were "cured" in the third year of therapy. The purpose of the BCG vaccination was to give immunity in children against tuberculous infection, whereas the ambulatory to adult patients with the positive sputum was aimed at reducing/ eradicating the source of infection. The BCG vaccination was carried out with the somcalled sweeping method until April 1973. Due to inadequate budged of the Ministry of Health, the Foundation of the Indonesian Tuberculosis Association was established in 1968 to assist the Ministry of Heallth in the eradication of pulmonary tuberculosis.

The coverage of the BCG vaccinatilon in North Sumatra was, however, far below the target, i.e. only $34,4 \%$, with the following specification: $27,2 \%$ for the age group of under 5 years and $38,8 \%$ for the age group of 4 - 14 years. Probably the coverage of the $B C G$ vaccination in other provinces of Indonesia is more or less equally low. So as a matter of priority jt would be more rational and effective if all the available funds and forces (which are still inadequate) for the BCG vaccination be given to those age groups of under 5 years, so thais the $75 \%$ coverage might be achieved in due time. This of course meanis sacrificing the olldier children by not giving them $B C G$ vaccination.
However, if those children who are older than 5 years will become infected, the chance of getting tuberculous meningitis as a complication is much smaller; and even if they might contract tuberculous meningitis, the mortality rate will also be much lower ( $\pm 1 / 4$ time) (see table 2 ).

It is generally believed that the BCG efficacy diminishes after 10 years. For a country 'with a high prevalence of tuberculosis (like Indonesia), it would be advisable to revaccinate after 10 years (Toman, 1973). This means that afiter 10 years all the children at the age of 10 - 14 years should be revaccinated, and also those children (10-14 years old) without BCG scar should be vaccinated (primarily $B C G$ vaccination). The prospect of the $\mathrm{BCG}$ vaccination, now included in the smallpox vaccination program of achieving a coverage more than $75 \%$ in the young chlidren below the age of 5 years, is certainly much better. It will be even hopeful if more aid could be obtained from the Indonesian Tuberculosis Association.

The resulits of the tuberculin test of 3 months to 2 years after the $\mathrm{BCG}$ vaccination showed a wide range: $33,7 \%$ in children $(1-14$ years $0: d)$ of the PNP- eistate, 65,9\% in chilldren 6 years old') in the regency of Tanah Karo, and 78,9\% in infants born in the RSUPP. What does it means? Does it mean that the poitency of the $B C G$ vaccine is variable or that the (errors in the) 
technique of the $B C G$ vaccination is different? Errons in the tuberculin testing are less likely, for old tuberculin used was from the same batch and freshly prepared by the person. The tuberculin injection and the reading of the Mantoux test in the PNPIX estate and Tanah Karo were done by the same pedilatrilcians. The tuberculin testing and reading of the infants in the RSUPP were, however, carried out by another pediatrician. Could the A-typlical mycobacterium as well as nutritionail status play a factior of influence? Could it be assumed that the BCG efficacy was equally sitrong despite the discrepancy of the tuberculin testing? A conducted itrilal could posslibly answer to these quesitions. As the BCG vaccination will conltinue for a considerable time throughout Indonesta, it would be beneficial if the Ministry of $\mathrm{He}$ alth could fully suppont Biofarma Bandung in the production and utilization of the BCG vaccine. At present Biofarma Bandung produces BCG vaccine approximated 400.000 ampoules (a 50 doses), which are nearly the total amount neeted for the BCG campaign in the whole Indonesia (Kalligis, 1974).

Since the results of the supervised ambulatory intermittent chemotherapy in the Health Center chosen as a pillot project proved to be satisfying (83,5\% "quescent" in the 2nd year and 96.8\% "cured" in the 3rd year), it seems that the method of therapy, which in fact can reduce the source of infection in the familly, should be introduced in many more Health Center's.

From all patients hospitalized in the RSUPP (1964 - 1972) $18.9 \%$ had malnutrition, whereas from the tuberculous patients $37.7 \%$ were suffering from malnutrition. Therefore in the TB eradication programme the probllem of Protein Calorie Malnutrition, especially in young children under the age of 5 years, should also be dealt with.

\section{Conclusion}

As the incidence of tuberculous meningitis with a high mortality rate occurs mainly in young children below the age of 5 years and the available funds and forces for the TB eradication programme are still not sufficient yet, it is recommended that BCG vaccination should be implemented in children below the age of 5 years, in order to achieve a coverage of more than $80 \%$.

As the BCG efficacy decreases consivderably after 10 years, revaccination is advisable to children in the age group of 10 - 15 years. To decrease the source of TB infection in the familly which occurred about $50 \%$, the supervised ambulatory ireatment should be introduced to many more Health Centers. Besides BCG vaccination and chemotherapy, the nutr1- 
tional status of children should also be improved. Last but not least, for the successful implementation of the TB eradication programme more aid is needed from the Indonesian Tuberculosis Association (PPTI).

\section{Acknowledgement}

The authors like to express their gratitude to both the Board of the
PNP-IX estate and the Board of the PPTI of North Sumatra for all the survey of tuberculin testing, and to the Heads of the Department of Pediatrics in Bandung, Jakarta, Yogyakarta, Ujung Pandang and Surabaya for collecting data of tuberculous meningitis.

\section{REFERENCES}

1. CILOTO WORKSHOP ON TB/BCG, January (1969).

2. GUNARDI, A.S. : Dasar-dasar pemberantasan penyakit Tbc paru-paru. Newsletter PPTI th. IV hhal. 9 - 10 April 1974.

3. JO KIAN TJAY : Pidato pengukuhan guru besar dalam Ilmu Kesehatar Anak, Fakultas Kedokteran Universitas Sumatra Utara, 1965.

4. JO KIAN TJAY, P. HARNOPIDJATI dan SYARIKAT TARIGAN : Meningitis tuberculosis pada anak di tiga rumah sakit di Medan. Seminar Tuberculosis yang diselenggarakan oleh $\mathrm{Pa}$ nitia Peningkatan Ilmu Fak. Ked. USU Medan, Agustus 1971.

5. JO KIAN TJAY, T. IRAWATI, S. HALIM, SYARIKAT TARIGAN dan H.R. SOEROSO : Epidemiologi primer tbc pada anak di Medan. Seminar Tuberculosis yang diselenggarakan oleh Panitia Peningkatan Ilmu Fak. Ked. USU Medan, Agustus 1971.

6. KALIGIS, A.J.J. : Produksi BCG vak$\sin$ (Komunikasi pribadi, 30 Apru 1974).

7. LOTTE, A. : Tuberculosis in children. A cooperative study in Europe, News- letter PPTI th. III, No. 10 (June \& July 1973).

8. MORRISON, J.B. : Natural history of segmental lesion in primary pulmonary tuberculosis. Arch. Dis. Childh. $48: 90$ - 98 (1973).

9. POEY SENG HIN : Kwashiorkor di Jakarta dan sekitarnya (Thesis, Universitas Indonesia, Jakarta 1956).

10. PPTI : Kongres I Jakarta Juli 1973.

11. SOEJONO D. POESPONEGORO dan JO KIAN TJAY : Tuberculosis Pri. mair pada anak, Maj. Kedokt. Indones. $8: 91$ (1958).

12. SUHAIMI HARUN T Setahun Pilot Proyek TB. Kontrol di Puskesmas Stabat Sumatra, Utara. Newsletter PPTI th. III No. 5 Jan. 1973.

13. SULASTOMO: Pusat Kesehatan Masyarakat dalam pemberantasan TBC. Newsletter PPTI th. IV/No. 1 hal $16-18$.

14. TATSURO IWASAKI : Tuberculosis problem in Asian Countries. Newsletter PPTI th. IV No. 1, 3, 4, 5 .

15. TOMAN, K. : The present status of technical knowledge concerning Immunization against tuberculosis. Boletin de la OSP. Vol. VII No. 2, 1973 (English Edition). 
TABLE 1 : Tuberculous Meningitis in Medan (1964 - 197\%).

\begin{tabular}{|c|c|c|c|c|c|c|c|}
\hline & \multirow{2}{*}{ Total } & \multicolumn{3}{|c|}{$S u r v i v e d$} & \multicolumn{3}{|c|}{$D$ i e d } \\
\hline & & $0-4 y$ & $5-12 y$ & Total & $0-4 y$ & $5-12 y$ & Total \\
\hline $\begin{array}{c}\text { RSUPP } \\
(1964-1972)\end{array}$ & 206 & 82 & 27 & 109 & 78 & 19 & 97 \\
\hline $\begin{array}{l}\text { RS PNP - IX } \\
(1964-1972)\end{array}$ & 25 & 8 & 3 & 11 & 12 & 2 & 14 \\
\hline \multirow{2}{*}{$\begin{array}{c}\text { RS ELIZABETH } \\
(1964-1970)\end{array}$} & 81 & 33 & 10 & 43 & 29 & 9 & 38 \\
\hline & 312 & 123 & 40 & 163 & $\begin{array}{c}119 \\
(79,7 \%)\end{array}$ & $\begin{array}{c}30 \\
(20,3 \%)\end{array}$ & $\begin{array}{c}149 \\
(47,8 \%)\end{array}$ \\
\hline
\end{tabular}

Note: 242 children or $77.5 \%$ out of 312 patients were under the age of 5 years.

TABLE 2 : Mortality rate in Tuberculous Meningitis

\begin{tabular}{|c|c|c|c|c|}
\hline & \multicolumn{2}{|c|}{$\mathrm{C}$ a $\mathrm{s}$ e $\mathrm{s}$} & \multicolumn{2}{|c|}{$D i e d$} \\
\hline & $0-14 y$ & $0-4 y$ & $0-4 y$ & $5-14 y$ \\
\hline $\begin{array}{c}M \text { e d a n } \\
(1964 ; 1972)\end{array}$ & 312 & $\begin{array}{c}242 \\
(77.5 \%)\end{array}$ & $\begin{array}{c}119 \\
(79.7 \%)\end{array}$ & $\begin{array}{c}30 \\
(20.3 \%)\end{array}$ \\
\hline $\begin{array}{l}\text { I a k a r t a } \\
(1968-1973)\end{array}$ & 919 & $\begin{array}{c}753 \\
(81.9 \%)\end{array}$ & $\begin{array}{c}320 \\
(82.3 \%)\end{array}$ & $\begin{array}{c}69 \\
(17.7 \%)\end{array}$ \\
\hline $\begin{array}{c}\text { Bandung } \\
(1968-1972)\end{array}$ & 630 & $\begin{array}{c}348 \\
(55.2 \%)\end{array}$ & $\begin{array}{c}52 \\
(82.5 \%)\end{array}$ & $\begin{array}{c}11 \\
(17.5 \%)\end{array}$ \\
\hline $\begin{array}{l}\text { Ujung Pandang } \\
(1970-1973)\end{array}$ & 167 & $\begin{array}{c}151 \\
(90.4 \%)\end{array}$ & $\begin{array}{c}59 \\
(88.1 \%)\end{array}$ & $\begin{array}{c}8 \\
(11.9 \%)\end{array}$ \\
\hline $\begin{array}{c}\text { Yogyalkarta } \\
(1972-1973)\end{array}$ & 64 & $\begin{array}{c}50 \\
(78.1 \%)\end{array}$ & $\begin{array}{c}13 \\
(65 \%)\end{array}$ & $\begin{array}{c}7 \\
(35 \%)\end{array}$ \\
\hline $\begin{array}{c}\text { Surabaya } \\
(1971-1973)\end{array}$ & 85 & $\begin{array}{c}81 \\
(94.1 \%)\end{array}$ & $\begin{array}{c}21 \\
(100 \%)\end{array}$ & $\begin{array}{c}0 \\
(0 \%)\end{array}$ \\
\hline
\end{tabular}


TABLE 3 : Distribution of lesions in chest $X$-ray film in childhood tuberculasis . Medan. (1970-1972).

\begin{tabular}{|c|c|c|c|c|c|c|c|c|}
\hline & \multirow{2}{*}{$\begin{array}{l}\text { Total } \\
\text { cases }\end{array}$} & \multicolumn{2}{|c|}{ Upper field } & \multicolumn{2}{|c|}{ Middle field } & \multicolumn{2}{|c|}{ Lower field } & \multirow{2}{*}{ Miliary } \\
\hline & & Right & Left & Right & Left & Right & Left & \\
\hline RSUP & 142 & 40 & 24 & 98 & 68 & 79 & 24 & 13 \\
\hline RS PNP & 88 & 14 & 10 & 65 & 50 & 53 & 17 & 0 \\
\hline \multirow[t]{5}{*}{ Total } & 230 & 54 & 34 & 163 & 118 & 132 & 41 & 13 \\
\hline & \multicolumn{3}{|c|}{ Mild - Moderate Lesion } & & & & & \\
\hline & \multicolumn{3}{|c|}{ Right lung } & & 349 & & & \\
\hline & \multicolumn{3}{|c|}{ Middle field } & & 281 & & & \\
\hline & \multicolumn{3}{|c|}{ Left lung } & & 193 & & & \\
\hline
\end{tabular}

TABLE 4 : BCG Vaccimation in North Sumatra (1970 - 19\%3).

\begin{tabular}{|c|c|c|c|c|}
\hline \multirow{2}{*}{ A $\mathrm{g} e$} & \multicolumn{3}{|c|}{$0-14 y$} & \multirow{2}{*}{$>15 \mathrm{y}$} \\
\hline & $0-4 y$ & $5-14 y$ & $0-14 y$ & \\
\hline Population & 1.283 .299 & 2.114 .026 & 3.397 .325 & 3.621 .704 \\
\hline BCG vac. & 348.578 & 820.712 & 1.169 .290 & 32.483 \\
\hline Coverage & $27.2 \%$ & $38.8 \%$ & $34.4 \%$ & $0.9 \%$ \\
\hline
\end{tabular}

